Abstract

\title{
Rheum ribes Extract Increase the Expression Level of miR-200 Family in Human Colorectal Cancer Cells ${ }^{\dagger}$
}

\author{
Ilknur Cinar *, Sumeyra Cetinkaya and H. Gul Dursun \\ Medical Biology Department, Meram Medical Faculty, Necmettin Erbakan University, Konya 42060, Turkey \\ * Correspondence: ilknurcinar@msn.com; Tel.: +90-05-349-711-135 \\ + Presented at the 2nd International Conference on Natural Products for Cancer Prevention and Therapy, \\ Kayseri, Turkey, 8-11 November 2017.
}

Publish: 15 November 2017

\begin{abstract}
Natural products obtained from plants have been used in the treatment of various diseases such as cancer since ancient times. Herbal medicine are the mixtures of therapeutic or preventive components, and so might have more activity than single purified chemicals alone. Rheum ribes species that one of the herbs commonly used in pharmacological researches. $R$. ribes has been determined that Rheum ribes plant species contain strong active compounds. The samples of the stem and root of Rheum ribes were dried and powdered, and then extracted with n-hexane, ethyl acetate and methanol solvents respectively. The cytotoxic effects of Rheum ribes extracts on HCT-116 and HT-29 cells were assessed using the XTT test. In order to determine the IC50 dose, plant extracts were applied to the cells at time $(24 \mathrm{~h}, 48 \mathrm{~h}, 72 \mathrm{~h})$ and dose-dependent at 50-1000 $\mu \mathrm{M}$. To examine the effects on miR-200 family of the methanol extract, expression profile of the target miRNAs (miR200a, miR-200b, miR-200c, miR-141) are determined by qPCR. According to the results, while the expression level of miR-200a and miR-141 increased in both cell lines, miR-200c increased only in dose group HCT116 cells compared with control cells. It is thought that R. Ribes extract may be significant agent for treatment of colorectal cancer.
\end{abstract}

Keywords: $R$. ribes; colorectal cancer; miRNA

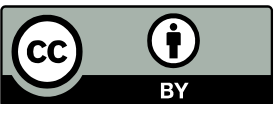

(C) 2017 by the authors. Licensee MDPI, Basel, Switzerland. This article is an open access article distributed under the terms and conditions of the Creative Commons Attribution (CC BY) license (http://creativecommons.org/licenses/by/4.0/). 